\title{
ENHANCED DELIGNIFICATION OF CORN STRAW WITH ALKALINE PRETREATMENT AT MILD TEMPERATURE
}

\author{
I.B.W. Gunam ${ }^{1, *}$, Y. Setiyo ${ }^{2}$, N.S. Antara', I.M.M. Wijaya ${ }^{1}$, I.W. Arnata \\ and I.W.W.P. Putra ${ }^{1}$ \\ ${ }^{1}$ Department of Agroindustrial Technology, Faculty of Agricultural Technology, Udayana \\ University, Badung, 80361 Bali, Indonesia \\ ${ }^{2}$ Department of Agricultural Engineering, Faculty of Agricultural Technology, Udayana \\ University, Badung, 80361 Bali, Indonesia \\ *E-mail: ibwgunam@unud.ac.id
}

\begin{abstract}
The lignocellulosic substrate bioconversion to produce fuel is very potential to be developed in the future. Converting cellulose to simple sugars requires a suitable and inexpensive preliminary treatment. This study aimed to investigate the use of alkali materials as chemicals suitable to delignify corn straw powder. The research was conducted to choose the chemical type for delignification, namely: $\mathrm{NaOH}, \mathrm{Ca}(\mathrm{OH})_{2}, \mathrm{NH}_{3}\left(\mathrm{NH}_{4} \mathrm{OH}\right)$, and Hydrazine. In the next step, the concentration of the delignification solution for corn straw powder was determined at material/chemical ratio of $1: 10(\mathrm{w} / \mathrm{v})$ and soaked for $8 \mathrm{~h}$ at room temperature. The tested alkaline solution concentrations were varied from $0,2,4,6$, to $8 \%(\mathrm{w} / \mathrm{v})$. The pre- and post pretreatments affected the yield of $\alpha$ cellulose, relative degree crystallinity by an X-Ray Diffraction (XRD), functional groups using a Fourier Transform Infra-Red (FT-IR) and surface morphology using a Scanning Electron Microscopy (SEM). Corn straw substrate in the best treatment will applied in the production of cellulase enzymes. The results showed that $\mathrm{NaOH}$ is the best used as a delignifying agent with the highest level of cellulose and the lowest lignin, namely $61.45 \%$ and $1.09 \%$, respectively. The $\mathrm{NaOH}$ solution at the concentration of $4 \%$ gives optimal results, with cellulose content $65.46 \%$, hemicellulose $14.58 \%$, and lignin $8.66 \%$. Based on FTIR, XRD and SEM analysis showed that alkali pretreatment especially with $\mathrm{NaOH}$ solution gives the result in which the corn straw cellulose structure becomes swelling.

Keywords: Corn Straw, Lignocellulose, Alkali Pretreatment, Sodium Hydroxide, Mild Temperature.
\end{abstract}

(C) RASĀYAN. All rights reserved

INTRODUCTION
Manufacturing chemical commodities ${ }^{1}$ and fuels with bioconversion of lignocellulosic biomass is considered as a prospective substitute to our current reliance on fossil fuels. ${ }^{2}$ Corn straw, as the agricultural waste, has high cellulose content ${ }^{3}$, allowing to be used as a growth medium for microorganisms to produce cellulase enzymes. To this point, the concentration of corn straw substrate is required for optimal cellulase enzyme production made of microorganisms in fermentation by using media from corn straw powder is not known. Making cellulase enzymes from corn straw waste as a substrate by using microorganisms as enzyme producers is easily cultured, has high growth rates, and is easily controlled for growth. ${ }^{4-5}$

Delignification is a process of removing lignin from lignocellulose complex compounds. This process is important before the cellulose material hydrolysis, because lignin can inhibit the penetration of acids or enzymes before hydrolysis takes place. By giving delignification treatment to the substrate, natural cellulose is expected to change its structure to be more amorphous, so that it becomes more easily hydrolyzed by cellulase enzymes. A variety of physical, chemical, and biological methods has been appraised for their technical feasibility at pre-treatment of lignocellulosic residues. These comprised alkali or acid treatment ${ }^{6}$. According to Irawan et al. $(2018)^{7}, \mathrm{NaOH}$ as one of the alkaline solutions effectively removes lignin from coconut coir. Arnata et al. (2019) ${ }^{8}$ also reported that delignification of sago frond with $10 \% \mathrm{NaOH}$ solution for $2 \mathrm{~h}$ is very effective in reducing lignin levels. In addition, the Rasayan J. Chem., 13(2), 1022-1029(2020) http://dx.doi.org/10.31788/RJC.2020.1325573 
higher the concentration of $\mathrm{NaOH}$ solution is, the ability to dissolve lignin and damage the structure of cellulose will increase and result in cellulose fibers which will be looser so that it is more easily used by microorganisms both for growth and for the production of cellulase enzymes. ${ }^{5,9}$

Delignification treatment of corn straw substrate by using $\mathrm{NaOH} 6 \%(\mathrm{w} / \mathrm{v})$ and substrate concentration of $2 \%(\mathrm{w} / \mathrm{v})$, can provide the highest enzyme endoglucanase activity. Besides that, if the substrate concentration is optimal, the enzyme activity will be high. ${ }^{10}$

\title{
Materials
}

\section{EXPERIMENTAL}

Fresh corn straw was collected a few hours after corn harvest from a field in Sanur Bali Indonesia. The chemicals for the preliminary treatment were: $\mathrm{NaOH}, \mathrm{Ca}(\mathrm{OH})_{2}, \mathrm{NH}_{3}\left(\mathrm{NH}_{4} \mathrm{OH}\right)$, and Hydrazine. Chemicals for analysis included: $\mathrm{HCl}, \mathrm{H}_{2} \mathrm{SO}_{4}$, etc. All chemicals were laboratory grade without further purification.

\section{Sample Preparation \\ Reducing the Size}

Lignocellulosic waste of corn straw was weighed and dried using an oven, up to $10 \%$ moisture content. After drying, it was crushed by a grinding tool. The grinding powder was sieved with a standard filter (Fisher Brand, Fisher Scientific International, Inc., Hampton, NH) between 60 mesh, and was carried at room temperature $\left(28-30^{\circ} \mathrm{C}\right)$. The resulting corn straw powder was stored in a cooler $\left(4^{\circ} \mathrm{C}\right)$ until it was used $^{11}$.

\begin{abstract}
Alkaline Pretreatment
This experiment was conducted under a completely randomized design with one factor, namely the chemical type, consisting of $\mathrm{NaOH}, \mathrm{Ca}(\mathrm{OH})_{2}, \mathrm{NH}_{3}$ (aqueous ammonia), and Hydrazine. Each treatment was repeated 3 times to obtain 12 experimental units.

Corn straw powder was weighed $5 \mathrm{~g}$ each, and each treatment was weighed 3 times, then put into a beaker and given a solution of $\mathrm{NaOH}, \mathrm{Ca}(\mathrm{OH})_{2}, \mathrm{NH}_{3}$, and Hydrazine each at a concentration of $4 \%(\mathrm{~b} / \mathrm{v})$ at a ratio of $1: 10(\mathrm{w} / \mathrm{v})$, soaked for $8 \mathrm{~h}$ at $28-30^{\circ} \mathrm{C}$. After pretreatment, the treated corn straw powder was recovered by filtration and rinsed with deionized water to reach $\mathrm{pH} 7.0$ and was dried in an oven at $60^{\circ} \mathrm{C}^{12}$. The obtained powder material was stored at $4^{\circ} \mathrm{C}^{7,13}$.
\end{abstract}

\section{Analysis of Cellulose and Lignin of Corn Straw Powder}

Prehydrolysates were centrifuged at $13,000 \mathrm{rpm}$ at $4^{\circ} \mathrm{C}$ for 10 mins. The accumulated supernatant was warmed at $60^{\circ} \mathrm{C}$ in a water bath, and $20 \% \mathrm{H}_{2} \mathrm{SO}_{4}$ was put with continuous stirring until $\mathrm{pH} 2$. The sample was cooled down in an ice bath to get a fast pellet. After centrifugated, the supernatant was poured (used later for hemicellulose extraction) and acid-insoluble lignin pellets were cleansed numerous times with acidified water $(\mathrm{pH} 2)$. Lignin pellets were dried and the weight was determined gravimetrically. After lignin precipited, the supernatant markers were used for hemicellulose extraction. The supernatant was added with anhydrous ethanol while stirring. The volumetric ratio of ethanol/filtrate was 4 . Hemicellulose was separated by centrifugation $(4,000 \mathrm{rpm}, 5 \mathrm{~min})$ and cleansed with ethanol until the supernatant was colorless. Finally, isolated hemicellulose was dehydrated in a vacuum oven at $50^{\circ} \mathrm{C}$ for $24 \mathrm{~h}$ and the weight was verified gravimetrically ${ }^{14,15}$.

\section{Analysis of Corn Straw Powder Structure Before and After Pretreatment}

The structure of corn straw powder before and after pretreatment was analyzed, respectively, with the benchmark testing system of the National Renewable Energy Laboratory (NREL), namely: FT-IR, XRD, and SEM analysis.

\section{Fourier Transform Infrared Spectroscopy (FT-IR)}

FT-IR spectroscopy is a proper procedure for verifying disparities introduced by distinctive treatments on the chemical structure of the isolated samples ${ }^{16-18}$. The structural components and chemical transformations in the samples of corn straw powder were probed with FT-IR ${ }^{14}$. 


\section{X-ray Diffraction (XRD) Analysis}

Cellulose crystallization of corn straw was analyzed with $\mathrm{XRD}^{19}$.

The sample of pretreatment corn straw powder was put into a sample bottle using X-ray Diffraction XRD 7000 maxima X (Shimadzu Ltd., Tokyo, Japan). X-pert pro diffractometer set at $40 \mathrm{KV}, 30 \mathrm{~mA}$; the radiation was $\mathrm{Cu} \mathrm{K} \alpha(\lambda=1.54 \AA)$, and grade range between $10(2 \theta)$ to $30^{\circ}(2 \theta)$ with a step size $0.03^{\circ}$.

\section{Scanning Electron Microscopy (SEM)}

The morphology of corn straw samples (delignification) was analyzed by SEM. SEM was conducted to analyze changes in microstructure and surface characteristics of corn straw samples ${ }^{15}$.

\section{Statistical Analysis}

It was carried out in triplicate and completed as a mean \pm standard deviation (SD). Statistical data were acquired by ANOVA and Duncan's multiple range test and a $p$-value $<0.01$ was assumed as a very significant difference.

\section{RESULTS AND DISCUSSION}

\section{Cellulose and Lignin Levels of Corn Straw Powder After Alkaline Pretreatment}

The analysis of variance results showed the treatment of variations regarding the type of delignifying solution which had a very significant effect $(\mathrm{p}<0.01)$ on the levels of cellulose and lignin. The average values of cellulose and lignin (Table-1).

Table-1: Average Values of Cellulose and Lignin Levels of Corn Straw Powder

\begin{tabular}{c|c|c}
\hline Pretreatment & Cellulose (\%) & Lignin (\%) \\
\hline $\mathrm{NaOH}$ & $61.45 \pm 0.717^{\mathrm{a}}$ & $1.09 \pm 0.006^{\mathrm{d}}$ \\
\hline $\mathrm{Ca}(\mathrm{OH})_{2}$ & $41.33 \pm 0.423^{\mathrm{c}}$ & $1.65 \pm 0.046^{\mathrm{c}}$ \\
\hline $\mathrm{NH}_{3}$ & $46.01 \pm 0.170^{\mathrm{b}}$ & $3.26 \pm 0.064^{\mathrm{a}}$ \\
\hline Hydrazine & $47.45 \pm 0.532^{\mathrm{b}}$ & $2.50 \pm 0.108^{\mathrm{b}}$ \\
\hline
\end{tabular}

Different letters behind the mean values indicated very significant differences $(p<0.01)$.

Table-1 showed that the highest cellulose content produced in the treatment with $\mathrm{NaOH}$ was $61.45 \%$, while the lowest cellulose content in the treatment with $\mathrm{Ca}(\mathrm{OH})_{2}$ solution was $41.33 \%$. The decrease in the highest lignin content was produced in the treatment with $\mathrm{NaOH}$ solution by $1.09 \%$, while the decrease in the lowest lignin content in the treatment with Ammonia solution was 3.26\%. The greater the level of lignin is, the lower the level of lignin will decrease due to the treatment of delignification solution. Cellulose content in high cell walls of plants is around $35-50 \%$ of the dry weight of plants ${ }^{20}$. The test results of the cellulose content in samples after delignification were significantly increased, whereas lignin levels decreased significantly. The decrease in lignin content may be caused by the use of a base solution which can dissolve lignin so that it is released from the lignocellulose bundle ${ }^{10}$. $\mathrm{NaOH}$ gives the best results in removing lignin and changing the structure of cellulose compared with $\mathrm{Ca}(\mathrm{OH})_{2}, \mathrm{Ammonia}$ and Hydrazine. The results of this research are supported by the results of several researchers who have reported that the $\mathrm{NaOH}$ treatment is a very proficient method to degrade and liquefy non-cellulose compounds by cleaving the $\alpha$ - and $\beta$-aryl ether linkages between lignin and hemicellulose ${ }^{21,22}$.

\section{Functional Groups by FT-IR}

FT-IR spectra of corn straw were presented in Fig.-1. There were differences in the wavenumber values of the absorption patterns within each functional group and the diversity in the merits of transmittance between the four treatments.

The vibrational absorption of compounds between wave numbers 2000 and $1000 \mathrm{~cm}^{-1}$ was related to cellulose, hemicellulose and lignin, which were related to each functional group of macromolecules. It should be noted that this signal was modified due to alkali treatment. In Fig.-1, spectra with vibrational uptake at wave number $2000 \mathrm{~cm}^{-1}$ in the spectrum of corn straw powder were associated with the stretching of aliphatic $\mathrm{C}-\mathrm{H}$ bonds. 
RASĀYAN J. Chem.

Vol. 13 | No. 2 |1022 - 1029| April - June | 2020

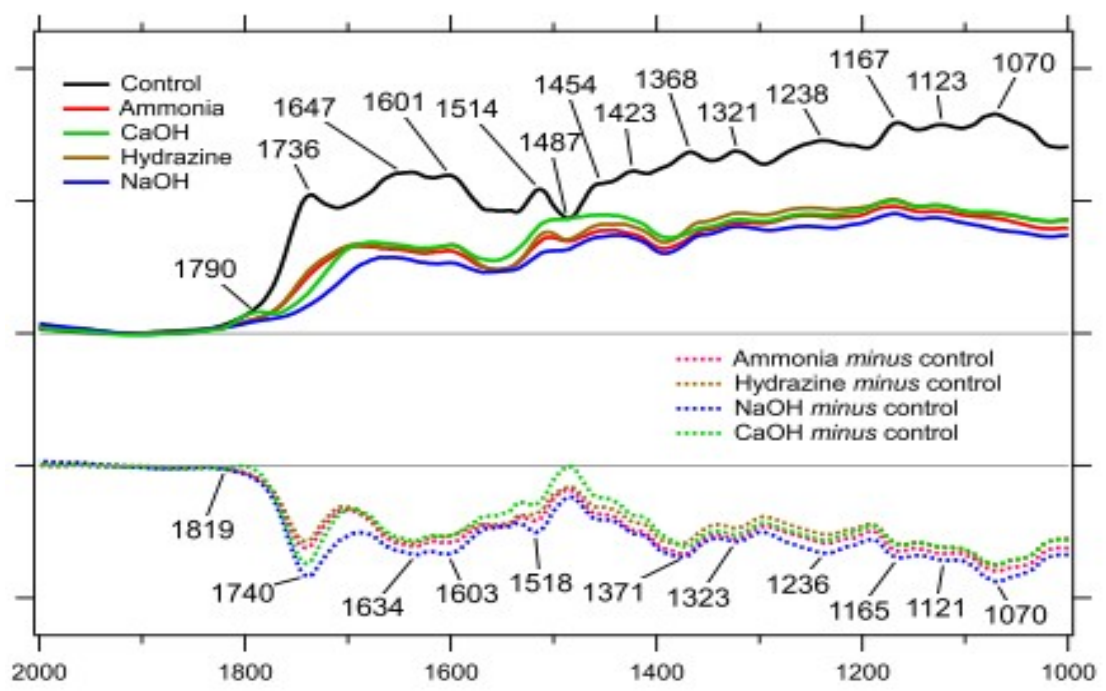

Fig.-1: FT-IR Spectra of Corn Straw Powder Delingnated with $\mathrm{NaOH}, \mathrm{Ca}(\mathrm{OH})_{2}, \mathrm{Ammonia}\left(\mathrm{NH}_{3}\right)$, and Hydrazine for $8 \mathrm{~h}$ at Room Temperature. Chemical Concentration was 4\% with a Ratio of Ingredients and Chemical Solution 1:

$10(\mathrm{w} / \mathrm{v})$. Y-axis Corresponds to Absorbance in Arbitrary unit, and X-axis is Wavenumber.

The absolute and difference FTIR spectra of each sample treated with specific base and spectra of ammonia minus control, hydrazine minus control, $\mathrm{NaOH}$ minus control and $\mathrm{Ca}(\mathrm{OH})_{2}$ minus control. The result of alkalization process, $\mathrm{OH}$ bond deformation in the absorption area around $1518 \mathrm{~cm}^{-1}$ indicated the water absorption by cellulose ${ }^{23}$ and may also indicating the presence of vibration of the guasil and lignin ring $^{24}$. The acetyl and ester groups in the hemicellulose, or the carboxyl acid group in the ferulic, and pcoumeric groups in lignin shown in spectra should be around $1740 \mathrm{~cm}^{-1}$, characterized by $\mathrm{C}=\mathrm{O}$ (carboxyl lignin vibration) groups, where $1236 \mathrm{~cm}^{-1}$ peak may indicate the presence of a siringil group in lignin ${ }^{25}$.

In addition, alkalization should also reduce vibrational uptake of the $\mathrm{C}=\mathrm{C}$ lignin spectra. Absorption area around $1420 \mathrm{~cm}^{-1}$ showed the existing $-\mathrm{CH}_{2}$ bond which was deformed in cellulose, where this region revealed crystalline part, and the uptake part was escalated ${ }^{26}$. The reaction occuring in the alkalization process was $\mathrm{NaOH}$ solution which dissociated into $\mathrm{Na}^{+}$and $\mathrm{OH}^{-}$then reacting with lignin. The $\mathrm{OH}^{-}$ion reacted with the $\mathrm{H}$ group of lignin to form $\mathrm{H}_{2} \mathrm{O}$. This would caused the $\mathrm{O}$ group to become free and reactive radicals with $\mathrm{C}$ forming $\mathrm{C}-\mathrm{O}-\mathrm{C}$. The $\mathrm{C}$ group already had four 'hands' so that a series of groups loosened to group $\mathrm{O}$. The reaction could produce two separate benzene rings, each of which had a reactive $\mathrm{O}$ group. This reactive $\mathrm{O}$ group reacted with $\mathrm{Na}^{+}$and dissolves in a basic solution so that lignin amount were reduced when rinsed. This reaction also produced $\mathrm{H}_{2} \mathrm{O}$. Meanwhile, cellulose is hydrophilic, so $\mathrm{H}_{2} \mathrm{O}$ is bound by cellulose which causes the concentration of $\mathrm{O}-\mathrm{H}$ bonds to increase, and the absorption area at $865.13 \mathrm{~cm}^{-1}$ showed $\mathrm{C}-\mathrm{H}$ vibrations indicating the absorption characteristics of $\beta$-glycosidic ${ }^{27,28}$, where the original absorption area was derived from $\beta$-glycosidic which connected between glucose units in cellulose $\mathrm{e}^{29-30}$.

From the results of the alkaline pretreatment showed above, the $\mathrm{NaOH}$ is the best performing base which can be seen from the decrement of the total amount of cellulose absorbance in Fig.-1. From this result, the solution was developed to obtain the best concentration of $\mathrm{NaOH}$. The following immersion data using $\mathrm{NaOH}$ concentrations of $0 \%, 2 \%, 4 \%$ and $6 \%$ were presented in Fig.-2 (characteristics of corn straw powder) and structure analysis using FT-IR (Fig.-3). The characteristics of corn straw powder before and after immersion with various concentrations of $\mathrm{NaOH}$ for $8 \mathrm{~h}$ at room temperature $\left(28-30^{\circ} \mathrm{C}\right)$ gave optimum results at $4 \% \mathrm{NaOH}$ concentration, namely cellulose levels of corn straw powder $65.46 \%$, hemicellulose $14.58 \%$, lignin $8.66 \%$, moisture content $6.51 \%$, ash $6.14 \%$ and hot water soluble (HWS) 5.80 .

From the FT-IR spectra in Fig.-3, it is appearing that $4 \%$ of $\mathrm{NaOH}$ concentration is the best concentration to be used seeing from the highest peak in the region between 1000 and $2000 \mathrm{~cm}^{-1}$. The delignated absorbance spectra were decreasing in corresponding increment of $\mathrm{NaOH}$ concentration, however only 
RASĀYAN J. Chem.

Vol. 13 | No. 2 |1022 - 1029| April - June | 2020

minute difference of absorbance was could be seen from Fig.-3 (dotted blue line). This indicate that there was no significant difference of treatment between $4 \%$ and $6 \%$ of $\mathrm{NaOH}$. Meanwhile the difference between $4 \%$ and $2 \%$ of $\mathrm{NaOH}$ gave significant difference in absorbance (red dotted line). This would indicate that $4 \%$ is the best concentration for delignification, where addition until $6 \%$ of $\mathrm{NaOH}$ will not improve the delignification significantly.

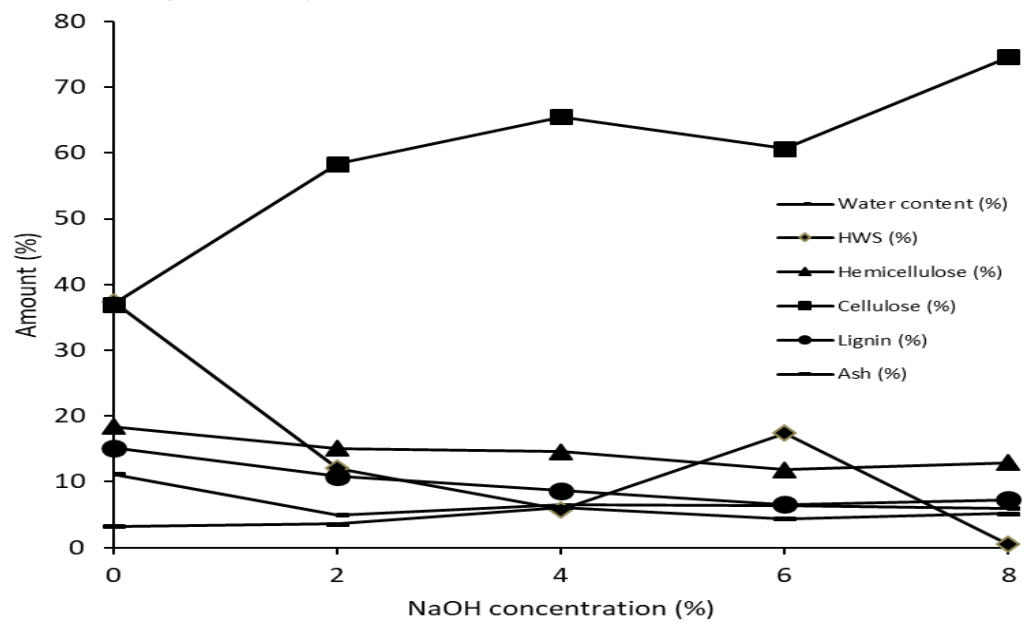

Fig.-2: The Characteristic Substrate of Corn Straw Powder after Soaking with 0, 2, 4, 6 and 8\% $\mathrm{NaOH}$ for $8 \mathrm{~h}$ at Room Temperature

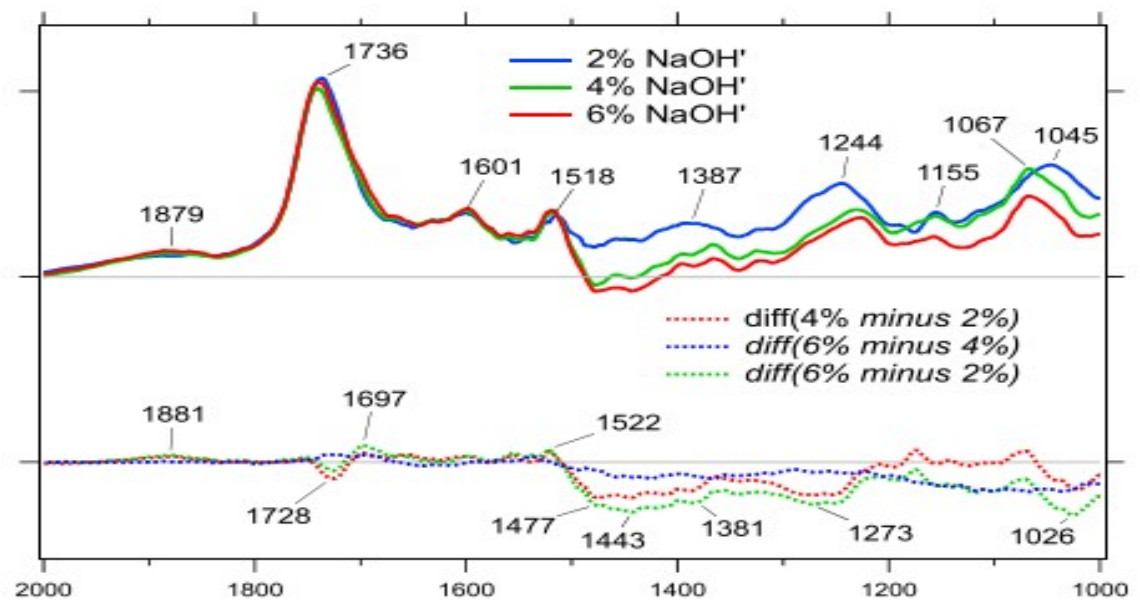

Fig.-3: FT-IR Spectra of Delignated Corn Straw Powder with Soaking Treatment of 2\%, 4\% and 6\% NaOH for $8 \mathrm{~h}$ at Room Temperature $\left(28-30^{\circ} \mathrm{C}\right)$. Y-axis Corresponds to Absorbance where each Division is 0.4 Absorbance Units,

\section{Surface Morphology}

and $\mathrm{X}$-axis is Wavenumber

The surface morphology of corn straw powder after delignification treatment with SEM were presented in Fig.-4. The research presented information on structural changes and surface properties which occur in corn straw after pretreatment with $\mathrm{NaOH}$. The cuticle wax coating on cornstarch had very low permeability to cellulose decomposing enzymes and it is hoped that pretreatment with $\mathrm{NaOH}$ could eliminate the surface of the outer granular wax and allowed direct contact with cellulase enzymes ${ }^{31}$. This research focuses on removing cuticle granules from non-cellulose materials using various concentrations of $\mathrm{NaOH}$ solution. Structure and SEM analysis were carried out on corn straw powder which had been given a pretreatment with $0 \% \mathrm{NaOH}$ solution (control), $2 \%, 4 \%$, and $6 \% \mathrm{NaOH}(\mathrm{w} / \mathrm{v})$. The analysis showed that the surface of natural corn straw powder (without $\mathrm{NaOH}$ ) looks flat, rough, and continuous. $\mathrm{NaOH}$ pretreatment damage to the external cell structure, raised external surface area and increased exposure to the internal cell structure as observed in the $4 \% \mathrm{NaOH}$ treatment. Pre-treated samples with 
RASĀYAN J. Chem.

Vol. 13 | No. 2 |1022 - 1029| April - June | 2020

$\mathrm{NaOH}$ were much softer and easier to digest by cellulase enzymes than natural samples $(\mathrm{NaOH} 0 \%)$, and the structure of lignocellulose wax layer was partially removed.

Delignified cracks could be seen on the surface of $4 \% \mathrm{NaOH}$ pretreated straw. Cracks were instigated by the elimination of easily digested lignocellulose fractions (such as hemicellulose). The partial deduction of lignin in $4 \% \mathrm{NaOH}$ resulted in swelling of biomass and disorder of lignin structure ${ }^{15}$.
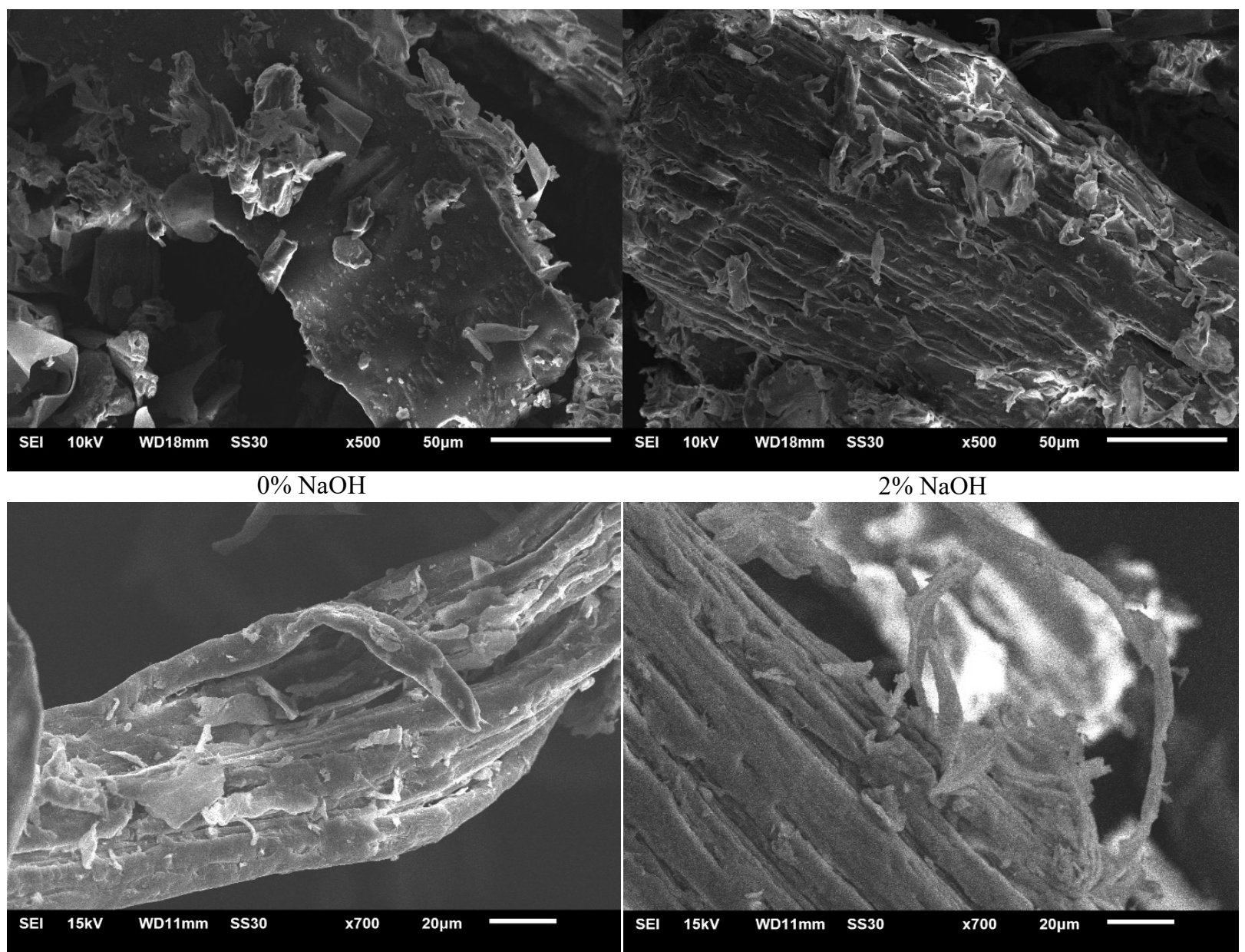

$4 \% \mathrm{NaOH}$

$6 \% \mathrm{NaOH}$

Fig.-4: SEM Images of Corn Straw Powder without Delignification $(0 \% \mathrm{NaOH}), 2 \%, 4 \%$ and $6 \% \mathrm{NaOH}$ Soaked for $8 \mathrm{~h}$ at Room Temperature $\left(28-30^{\circ} \mathrm{C}\right)$.

In Fig.-4, we can also see that the difference in a surface structure after treatment using $0 \%, 2 \%, 4 \%$ and $6 \% \mathrm{NaOH}$ for $8 \mathrm{~h}$ could increase the physical surface area of corn straw powder. This worked to increase the reaction of enzymes with the substrate i.e. corn straw powder and increase glucose levels resulted from enzymatic hydrolysis of solid residues ${ }^{31}$.

\section{Analysis with XRD}

Based on the analysis results of corn straw powder with XRD as shown in Fig.-5, It shows that chemical treatment causes a change in the crystallinity degree of cellulose corn straw powder. Corn straw and cellulose $^{32}$ have two main diffraction peaks, namely at $2 \theta=16^{\circ}$ and $2 \theta=22^{\circ}$ which are related to the crystalline planes of (110) and (200, respectively. In addition, low intensity peaks were observed at $2 \theta=$ $34^{\circ}$, which corresponded to the crystalline plane of (004). This diffraction pattern shows that corn straw cellulose has characteristics of natural cellulose structure or polymorph type cellulose I. This crystalline structure corresponded to the parallel arrangement between the linear chains of the glycosidic bonds of cellulose and had been referred to as polymorph cellulose with vaster mechanical endurance. 




Corn straw

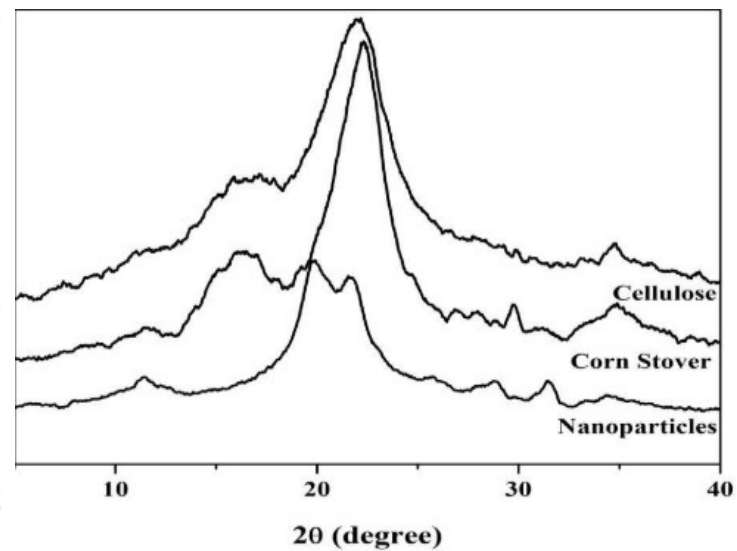

Costa et al. (2015)

Fig.-5: X-ray Diffraction (XRD) Patterns of Corn Straw Powder after Pretreatment with 4\% $\mathrm{NaOH}(\mathrm{A})$ and XRD Patterns of Pure Cellulose, Corncobs and Nanoparticle Material (B)

The XRD pattern of the nanoparticles had sharp peak intensities at $2 \theta=20.7^{\circ}$ and low intensities at $2 \theta=$ $11.4^{\circ}$ which corresponded to the crystalline and the remaining amorphous regions, respectively. Therefore, the original crystalline structure of cellulose did not change after acid hydrolysis. Based on the results of the graph above, it can be seen that the crystallinity degree of cellulose and cellulose nanoparticles were affected by the chemical usage in corn straw.

\section{CONCLUSION}

The results show $\mathrm{NaOH}$ is the best chemical as the delignifying agent with the highest levels of cellulose and the lowest lignin, namely $61.45 \%$ and $1.09 \%$, respectively. The $\mathrm{NaOH}$ solution at the concentration $4 \%$ gives optimal results, with cellulose content $65.46 \%$, hemicellulose $14.58 \%$, and lignin $8.66 \%$. FT-IR, XRD analysis and SEM also show the alkali treatment, especially with $\mathrm{NaOH}$ solution giving the result that the cellulose structure becomes swelling.

\section{ACKNOWLEDGEMENT}

The authors would like to gratitude to the Ministry of Research, Technology and Higher Education for the granting the fund through the Higher Education Applied Research (PTUPT) scheme (171.117/UN14.4.A/LT/2018).

\section{REFERENCES}

1. H. Kusumastuti, W. Trisunaryanti, I.I. Falah, and M.F. Marsuki, Rasayan Journal of Chemistry, 11(2), 522(2018), DOI: 10.31788/RJC.2018.1122061

2. S. Nakagame, R.P. Chandra, J.F. Kadla, and J.N. Saddler, Biotechnology and Bioengineering, 108(3), 538(2011), DOI:10.1002/bit.22981

3. H. Yu, X. Zhang, L. Song, J. Ke, C. Xu, W. Du, and J. Zhang, Journal of Bioscience and Bioengineering, 110(6), 660(2010), DOI:10.1016/j.jbiosc.2010.08.002

4. J.P.H. van Wyk and M. Mohulatsi, Bioresource Technology, 86, 21(2003), DOI:10.1016/S09608524(02)00130-X

5. I.B.W. Gunam, Hardiman, and T. Utami, in Proceeding of the $3^{\text {th }}$ Hokkaido Indonesian Student Association Scientific Meeting (HISAS 3), Sapporo, Hokkaido Japan, pp (2004).

6. A.S. Heerah, A. Mudhoo, R. Mohee and S.K. Sharma, Steam Pre-Treatment of Lignocellulosic Wastes for Biomethanogenesis: A Preliminary Study, Rasayan Journal of Chemistry, 1(3), 503(2008)

7. D. Irawan, N. Muslimah and Z. Arifin, Rasayan Journal of Chemistry, 11(4), 1458(2018), DOI: 10.31788/RJC.2018.1144039

8. I.W. Arnata, S. Suprihatin, F. Fahma, N. Richana, and T.C. Sunarti, Oriental Journal of Chemistry, 35 (Special Issue 1), 08(2019), DOI:10.13005/ojc/35Specialissue102 
9. S.H. Lee, T.V. Doherty, R.J. Linhardt, J. S. Dordick, Biotechnology and Bioengineering, 102(5), 1368(2009), DOI: 10.1002/bit.22179

10. I.B.W. Gunam, W.R. Aryanta, I.B.N.S Darma, Jurnal Biologi, 15(2), 29(2011).

11. I.B.W. Gunam, N.S. Antara, A.A.M.D. Anggreni, Y. Setiyo, IP.E. Wiguna, I. M.M. Wijaya, and IW.W.P. Putra, AIP Conference Proceedings, 2155, 020040(2019), DOI:10.1063/1.5125544

12. R. Kumar, G. Mago, V. Balan, and C.E. Wyman, Bioresource Technology, 100(17), 3948(2009), DOI:10.1016/j.biortech.2009.01.075

13. Y.C. Park and J.S. Kim, Energy, 47(1), 31(2012), DOI: 10.1016/j.energy.2012.08.010

14. X. Liu, A. Wang, L. Li, T. Zhang, C-Y. Mou, J-F. Lee, Journal of Catalysis, 278(2), 288(2011), DOI:10.1016/j.jcat.2010.12.016

15. Md. A. Haque, D.N. Barman, T.H. Kang, M.K. Kim, J. Kim, H. Kim, and H.D. Yun, Journal of Microbiology and Biotechnology, 22(12), 1681(2012), DOI:10.4014/jmb.1206.06058

16. R. Zuluaga, J.L. Putaux, J. Cruz, J. Vélez, I. Mondragon, P. Gañán, Carbohydrate Polymers, 76, 51(2009), DOI:10.1016/j.carbpol.2008.09.024

17. Y. Rilda, D.R. Ratyaningsih, Y.E. Putri, R. Syukri, A. Agustien, and H. Pardi, Rasayan Journal of Chemistry, 13(1), 255(2020), DOI:10.31788/RJC.2020.1315673

18. A.A.S.A. Sukmaningsih, S. Permana, D.J.D.H. Santjojo, A.Y.P. Wardoyo, and S.B. Sumitro, Rasayan Journal of Chemistry, 11(3), 1193(2018), DOI: 10.31788/RJC.2018.1133047

19. L. Segal, J.J. Creely, Jr.A.E. Martin, and C.M. Conrad, Textile Research Journal, 29, 786(1959), DOI: $10.1177 / 004051755902901003$

20. L.R. Lynd, P.J. Weimer, W.H. van Zyl, and I.S. Pretorius, Microbiology and Molecular Biology Reviews, 66(3), 506(2002), DOI: 10.1128/MMBR.66.3.506-577.2002

21. S. Singh, S.T. P. Bharadwaja, P.K.Yadav, V.S. Moholkar, and A. Goyal, Industrial \& Engineering Chemistry Research, 53(37), 14241(2014), DOI: 10.1021/ie502339q

22. Y. Yue, J. Han, G. Han, G.M. Aita, and Q. Wu, Industrial Crops and Products, 76, 355(2015), DOI: 10.1016/j.indcrop.2015.07.006

23. J. Łojewska, P. Miśkowiec, T. Łojewski, and L.M. Proniewicz, Polymer Degradation and Stability, 88(3), 512(2005), DOI:10.1016/j.polymdegradstab.2004.12.012

24. C-F. Liu, J-L. Ren. F. Xu. J-J. Liu, J-X. Sun, R-C. Sun, Journal of Agricultural and Food Chemistry, 54(16), 5742(2006), DOI:10.1021/jf060929o

25. M. Poletto, H.L. Ornaghi, A.J. Zattera, Materials, 7(9), 6105(2014), DOI: 10.3390/ma7096105

26. B. Shanmugarajah, P.L. Kiew, I.M.L. Chew, T.S.Y. Choong, and K.W. Tan, Chemical Engineering Transactions, 45, 1705(2015), DOI:10.3303/CET1545285

27. O. Chaikumpollert, P. Methacanon, K. Suchiva, Carbohydrate Polymers, 57(2), 191(2004), DOI: 10.1016/j.carbpol.2004.04.011

28. S. Elanthikkal, U. Gopalakrishnapanicker, S. Varghese, and J.T. Guthrie, Carbohydrate Polymers, 80(3), 852(2010), DOI:10.1016/j.carbpol.2009.12.043

29. X-F. Sun, R-C. Sun, Y. Su, and J-X. Sun, Journal of Agricultural and Food Chemistry, 52(4), 839(2004), DOI:10.1021/jf0349230

30. A. Alemdar and M. Sain, Bioresource Technology, 99(6), 1664(2008), DOI: 10.1016/j.biortech.2007.04.029

31. K. Satyanagalakshmi, R. Sindhu, P. Binod, K.U. Janu, R.K. Sukumaran, and A. Pandey, Journal of Scientific and Industrial Research, 70(2), 156(2011).

32. L.A.S. Costa, D.de J. Assis, G.V.P. Gomes, J.B.A. Da Silva, A.F. Fonsêca, and J.I. Druzian, Materials Today: Proceedings, 2(1), 287(2015), DOI:10.1016/j.matpr.2015.04.045

[RJC-5573/2019] 